\title{
Railway transportation as a serious source of organic and inorganic pollution
}

\author{
B. Wilkomirski • B. Sudnik-Wójcikowska • \\ H. Galera • M. Wierzbicka • M. Malawska
}

Received: 7 May 2010 / Accepted: 24 September 2010 /Published online: 8 October 2010

(C) The Author(s) 2010. This article is published with open access at Springerlink.com

\begin{abstract}
Polycyclic aromatic hydrocarbons and heavy metal ( $\mathrm{Pb}, \mathrm{Cd}, \mathrm{Cu}, \mathrm{Zn}, \mathrm{Hg}, \mathrm{Fe}, \mathrm{Co}, \mathrm{Cr}, \mathrm{Mo})$ contents were established in soil and plant samples collected in different areas of the railway junction Iława Główna, Poland. Soil and plant samples were collected in four functional parts of the junction, i.e. the loading ramp, main track within platform area, rolling stock cleaning bay and the railway siding. It was found that all the investigated areas were strongly contaminated with polycyclic aromatic hydrocarbons (PAHs). The PAH contamination of the soil was the highest in the railway siding and in the platform area (59,508 and 49,670 $\mu \mathrm{g} \mathrm{kg}^{-1}$, respectively). In the loading ramp and cleaning bay, the PAH concentration in soil was lower but still relatively very high (17,948 and 15,376 $\mu \mathrm{g} \mathrm{kg}$, respectively). The contamination in the railway siding exceeded the average control level up to about 80 times. In the soil of all the investigated areas, four- and five-ring PAHs prevailed. The concentrations of PAHs were determined in four dominating species of plants found at the junction. The highest concentration was found in the aerial parts of Taraxacum officinale $\left(22,492 \mu \mathrm{g} \mathrm{kg}^{-1}\right)$ growing in the cleaning bay. The comparison of the soil contamination with PAHs in the investigated
\end{abstract}

B. Wiłkomirski $(\bowtie) \cdot$ B. Sudnik-Wójcikowska •

H. Galera $\cdot$ M. Wierzbicka $\cdot$ M. Malawska Institute of Botany, University of Warsaw,

Al. Ujazdowskie 4,

00-478 Warsaw, Poland

e-mail: bowi@biol.uw.edu.pl railway junction showed a very significant increase of the PAHs level since 1995. It was found that the heavy metal contamination was also very high. $\mathrm{Pb}, \mathrm{Zn}, \mathrm{Hg}$ and $\mathrm{Cd}$ were established at the highest levels in the railway siding area, whereas $\mathrm{Fe}$ concentration was the highest in the platform area. A significant increase in mercury content was observed in the cleaning bay area. The investigations proved very significant increase of contamination with PAHs and similar heavy metals contamination in comparison with the concentration determined in the same areas 13 years ago.

Keywords Railway · Soil · Plants · Contamination · Heavy metals $\cdot$ PAHs

\section{Introduction}

The railway is one of the most fundamental (apart from roads) means of transportation. In Poland, the rail has used some areas for more than 150 years. It has been commonly thought that rail transportation is much less harmful to the environment than road traffic. However, the specificity of rail causes some typical organic and inorganic contamination (Malawska and Wiłkomirski 1999, 2000, 2001; Lacey and Cole 2003; Liu et al. 2009), resulting mostly from used lubricate oils and condenser fluids, transportation of oil derivatives, metal ores, fertilizers and different chemicals, as well as from application of herbicides. The two most important types of pollutants connected with railway 
transport are polycyclic aromatic hydrocarbons (PAHs) and heavy metals. Besides high toxicity, significant stability and a cumulative effect in the environment PAHs have a peculiar feature, which is the carcinogenic and mutagenic effect on living organisms (IARC 1983). The main source of PAHs in railway areas derives from substances used for rolling stock exploitation such as machine grease, fuel oils and transformers oils. Another important source of PAHs is creosote, which is a common impregnation agent for outdoor wood structures, including railway ties (Brooks 2004; Moret et al. 2007; Thierfelder and Sandström 2008). Heavy metals are amongst the most frequently found and intensively studied chemical substances that contaminate the environment. Railway areas are thought to be sites of intensive heavy metal emission, and there are some interesting articles dealing with this problem (Chillrud et al. 2005; Bukowiecki et al. 2007; Liu et al. 2009). The rail rolling stock construction material abrasion, fuel combustion in diesel-electric locomotives, action of pantographs on trolley wires and cargo leakage emit particles containing heavy metals into the air and subsequently deposit them into the plant and soil through dry and wet deposition.

The first aim of this work is to present information concerning the pollution level of soil and plants with heavy metals ( $\mathrm{Pb}, \mathrm{Cd}, \mathrm{Cu}, \mathrm{Zn}, \mathrm{Hg}, \mathrm{Fe}, \mathrm{Co}, \mathrm{Cr}, \mathrm{Mo}$ ) and 17 PAHs in the area of four functional parts of the railway junction Iława Główna (Poland). Similar investigations were performed 13 years ago (Malawska and Wiłkomirski 2001); hence, the second aim is to compare the presents results with previous findings and to provide evidence that railway transport is the source of the above contamination.

\section{Materials and methods}

\subsection{Study area}

The investigations were carried out in the area of the railway junction Iława Główna located in northern Poland about $200 \mathrm{~km}$ north of Warsaw on the Warsaw-Gdańsk railway route in the western part of the Mazurian Lake Region. This region covered mostly by forests and lakes is relatively clean, since no heavy industry is concentrated there. The junction having such location is the relevant place to investigate the influence of railway transportation on environmental pollution. After World War II, the very old railway junction Iława Główna (built in 1870) became an important junction in Polish Railway Network. Very heavy passenger and goods traffic is concentrated in the area of the junction because Ilawa Główna is situated at the crossing of a few important railway routes. The railway junction covers an area of almost $2 \mathrm{~km}^{2}$ within which the different functional parts are situated. Our investigations were carried out at four sites of the junction:

1. The railway siding (in tables and figures referred to as "siding") which consists of many tracks where goods trains wait for unloading. The sampling area was situated in the most frequently used track of the railway siding $\left(53^{\circ} 34^{\prime} 67.5^{\prime \prime} \mathrm{N}\right.$; $19^{\circ} 34^{\prime} 34.0^{\prime \prime} \mathrm{E}$ )

2. The loading station (referred to as "loading") which is the track located close to the loading platform where different goods (at present mostly coal) are reloaded from hopper wagons to heavy lorries $\left(53^{\circ} 35^{\prime} 09.4^{\prime \prime} \mathrm{N} ; 19^{\circ} 34^{\prime} 39.7^{\prime \prime} \mathrm{E}\right)$

3. Track no. 7 (referred to as "platform") which is located in the passenger part of the junction and focuses main stream of local and long distance trains $\left(53^{\circ} 34^{\prime} 55.0^{\prime \prime} \mathrm{N} ; 19^{\circ} 34^{\prime} 26.1^{\prime \prime} \mathrm{E}\right)$

4. The rolling stock cleaning bay (referred to as "cleaning") which is the separated and unsecured railway track with no facilities preventing the leakage $\left(53^{\circ} 34^{\prime} 49.0^{\prime \prime} \mathrm{N} ; 1^{\circ} 34^{\prime} 20.1^{\prime \prime} \mathrm{E}\right)$

\subsection{Soil and plant sampling}

At each of the four investigated sites, a surface covering a total of $120 \mathrm{~m}^{2}$ was established. The surface consisted of two subsurfaces $\left(60 \mathrm{~m}^{2}\right.$ each): the first covering a fragment of the tracks situated between the rails (rail gauge) and the second one located outside both rails up to the end of railway ties. This allowed us to find the potential differences between the level of contamination inside and outside rails. The diagram illustrating the method of soil sampling in each investigated area is presented in Fig. 1.

Soil samples were collected in predetermined investigation areas in September 2008. The railway basement soil collected from the depth of $0-20 \mathrm{~cm}$ was sieved ( $5 \mathrm{~mm}$ sieve) directly at the sampling area. Each time, 15-20 individual samples were taken 
Fig. 1 Method of soil sampling

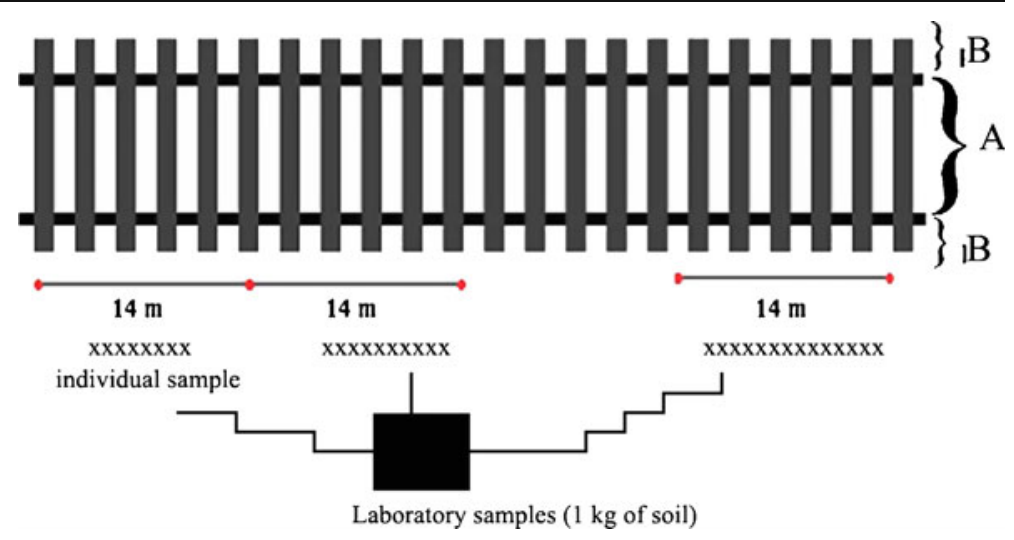

thereby providing a mean mixed sample of about $1 \mathrm{~kg}$ of the soil representing ballast bed either from the subsurface located between the rails or outside rails. Dried soil samples were sieved (1 mm sieve) in the laboratory and used for further analysis.

The reference soil samples were collected at three points: (1) the vicinity of a small factory about $500 \mathrm{~m}$ southwest of the railway junction $\left(53^{\circ} 34^{\prime} 44.6^{\prime \prime} \mathrm{N} ; 19^{\circ}\right.$ $\left.34^{\prime} 13.1^{\prime \prime} \mathrm{E}\right)$, (2) hilly field about $500 \mathrm{~m}$ southeast of the railway junction $\left(53^{\circ} 34^{\prime} 43.2^{\prime \prime} \mathrm{N} ; 1^{\circ} 34^{\prime} 33.4^{\prime \prime} \mathrm{E}\right)$ and (3) field in the suburb town of Iława about $2 \mathrm{~km}$ east of the railway junction ( $\left.53^{\circ} 34^{\prime} 52.4^{\prime \prime} \mathrm{N} ; 1^{\circ} 35^{\prime} 05.7^{\prime \prime} \mathrm{E}\right)$.

\subsection{Determination of PAHs and heavy metals}

The extraction of plant and soil samples was performed with the use of dichloromethane. Further purification was carried out on Florisil. The PAH content analysis in plant and soil material was performed using a gas chromatograph equipped with a mass detector (GC/MSD Agilent Technologies $6890 \mathrm{~N} / 5973$ ) and a non-polar capillary column HP$5 \mathrm{MS}$ (length $50 \mathrm{~m}$, diameter $0.2 \mathrm{~mm}, 0.3 \mu \mathrm{m}$ diphenyl-95\% dimethylpolysiloxane film). Temperature programming was applied: $70^{\circ} \mathrm{C} \pm 10^{\circ} \mathrm{C} \mathrm{min}^{-1}$ to $200^{\circ} \mathrm{C}, \pm 2^{\circ} \mathrm{C} \mathrm{min}^{-1}$ to $300^{\circ} \mathrm{C}(2 \mathrm{~min})$. The detector temperature was $280^{\circ} \mathrm{C}$. The temperature of injection port was $250^{\circ} \mathrm{C}$. The quantitative analysis was performed using the external standard method where the certified PM-612 standard (Ultra Scientific Ltd) was applied for PAHs except benzo[e]pyrene and perylene for which certified standard 15 RM-612 (LGC Standard) was applied. The carrier gas was helium - flow rate $1 \mathrm{ml} / \mathrm{min}$.

The following 17 PAHs were determined: acenaphthylene, acenaphthene, fluorene, phenanthrene, anthracene, fluoranthene, pyrene, benzo[a]anthracene, chrysene, benzo [b]fluoranthene, benzo[k]fluoranthene, benzo[e]pyrene, benzo[a]pyrene, perylene, indeno[123-cd]pyrene, dibenzo [ah]anthracene and benzo[ghi]perylene.

The entire analytical procedure underwent quality control checks. Analyses of blanks were performed for every eight samples. PAH concentrations in all blank values were below the detection limit.

Heavy metal analyses were carried out after mineralization using nitric acid and microwaves for plant samples and aqua regia in open system for soil samples. The mercury content was established by the total mercury assessment technique with an AMA 254 analyser. The other heavy metal contents $(\mathrm{Pb}, \mathrm{Cd}, \mathrm{Cu}$, $\mathrm{Zn}, \mathrm{Fe}, \mathrm{Co}, \mathrm{Cr}, \mathrm{Mo}$ ) were established by the inductively coupled plasma (ICP) mass spectroscopy technique for plants and ICP-optical emission spectrometry technique for soil samples. The quality assurance and quality control was performed by analyzing the standard samples of known composition. All the analyses (PAHs and heavy metals) were carried out in Central Chemical Laboratory of Polish Geological Institute which possesses accreditation certificate AB 283.

\section{Results and discussion}

The levels of PAHs were determined in soil samples and selected plants. The PAH contents in the soil collected from the four functional parts of the junction, i.e. "siding", "loading", "platform" and "cleaning", are presented in Table 1. The results obtained from each study area are represented by two values, i.e. $A$ (between rails - rail gauge) and $B$ (shoulder outside rails). Control values represented 
Table 1 Content of PAHs in soil samples taken from the railway junction Iława Główna depending on place (micrograms per kilogram)

\begin{tabular}{|c|c|c|c|c|c|c|c|c|c|c|c|}
\hline \multirow[t]{2}{*}{ Compounds } & \multicolumn{2}{|c|}{ Siding } & \multicolumn{2}{|c|}{ Loading } & \multicolumn{2}{|c|}{ Platform } & \multicolumn{2}{|c|}{ Cleaning } & \multicolumn{3}{|c|}{ Control } \\
\hline & $A$ & $B$ & $A$ & $B$ & $A$ & $B$ & $A$ & $B$ & 1 & 2 & 3 \\
\hline Acenaphthylene & 240 & 352 & 106 & 65 & 333 & 172 & 125 & 92 & 2 & 4 & 2 \\
\hline Acenaphthene & 443 & 347 & 53 & 51 & 480 & 326 & 65 & 27 & 1 & 2 & 2 \\
\hline Fluorene & 396 & 349 & 86 & 76 & 455 & 418 & 69 & 43 & 1 & 3 & 2 \\
\hline Phenanthrene & 5,000 & 4,500 & 1,318 & 1,186 & 5,700 & 4,300 & 1,149 & 666 & 39 & 64 & 35 \\
\hline Anthracene & 1,584 & 1,558 & 427 & 287 & 1,023 & 866 & 530 & 289 & 7 & 6 & 3 \\
\hline Fluoranthene & 8,900 & 7,400 & 2,650 & 2,450 & 8,100 & 6,800 & 2,380 & 1,188 & 135 & 133 & 69 \\
\hline Pyrene & 7,600 & 6,200 & 2,640 & 2,180 & 6,700 & 5,700 & 2,170 & 1,189 & 114 & 101 & 54 \\
\hline Benzo[a]anthracene & 4,900 & 5,300 & 1,275 & 1,142 & 3,300 & 2,970 & 1,047 & 511 & 60 & 48 & 24 \\
\hline Chrysene & 4,400 & 4,700 & 1,359 & 1,183 & 3,500 & 2,860 & 1,181 & 565 & 70 & 73 & 32 \\
\hline Benzo[b]fluoranthene & 5,900 & 6,300 & 2,160 & 1,626 & 4,700 & 3,700 & 1,719 & 791 & 92 & 83 & 35 \\
\hline Benzo[k]fluoranthene & 2,650 & 2,900 & 871 & 715 & 1,976 & 1,630 & 686 & 341 & 49 & 42 & 18 \\
\hline Benzo[e]pyrene & 2,290 & 2,510 & 841 & 659 & 1,939 & 1,484 & 668 & 361 & 75 & 64 & 28 \\
\hline Benzo[a]pyrene & 5,300 & 5,800 & 1,348 & 1,192 & 3,500 & 3,200 & 1,085 & 537 & 85 & 59 & 28 \\
\hline Perylene & 869 & 937 & 228 & 204 & 551 & 509 & 187 & 99 & 21 & 13 & 5 \\
\hline Indeno[123-cd]pyrene & 4,300 & 4,700 & 1,265 & 1,061 & 3,400 & 2,850 & 1,026 & 562 & 83 & 73 & 25 \\
\hline Dibenzo[ah]anthracene & 936 & 1,032 & 211 & 218 & 713 & 601 & 220 & 116 & 15 & 12 & 5 \\
\hline Benzo[ghi]perylene & 3,800 & 4,100 & 1,110 & 940 & 3,300 & 2,640 & 1,069 & 609 & 83 & 70 & 24 \\
\hline
\end{tabular}

results obtained from the three described reference areas, respectively.

Whilst analyzing the total PAHs found in soil in different parts of the railway junction Iława Główna, the highest concentrations of these substances were detected in the platform and railway siding areas reaching in siding 59,508 and 58,985 $\mathrm{\mu g} \mathrm{kg}^{-1}$ ( $A$ and $B$, respectively) and in platform 49,670 and $41,026 \mu \mathrm{g} \mathrm{kg}^{-1}$ ( $A$ and $B$, respectively). The concentration of PAHs in the loading ramp was placed at the level 17,948 and $41,026 \mu \mathrm{g} \mathrm{kg}^{-1}$ ( $A$ and $B$, respectively). Amongst the investigated functional parts of the junction, the lowest contamination was detected in the cleaning bay area, reaching 15,376 and $7,986 \mu \mathrm{g} \mathrm{kg}^{-1}$ ( $A$ and $B$, respectively). Figure 2 presented the comparison of total PAHs content in rail gauge $(A)$ and shoulder $(B)$. In all the investigated areas, the total PAHs content is slightly higher in transect $A$ than in transect $B$. All amounts are significantly higher than the amount of PAHs in control areas.

The PAHs concentration in soil of the three reference areas varied from 391 to $932 \mu \mathrm{g} \mathrm{kg}^{-1}$. In all the investigated areas, the level of PAHs in the rail
Fig. 2 The comparison of total PAH content in soil of transect $A$ and transect $B$ depending on place (micrograms per kilogram)

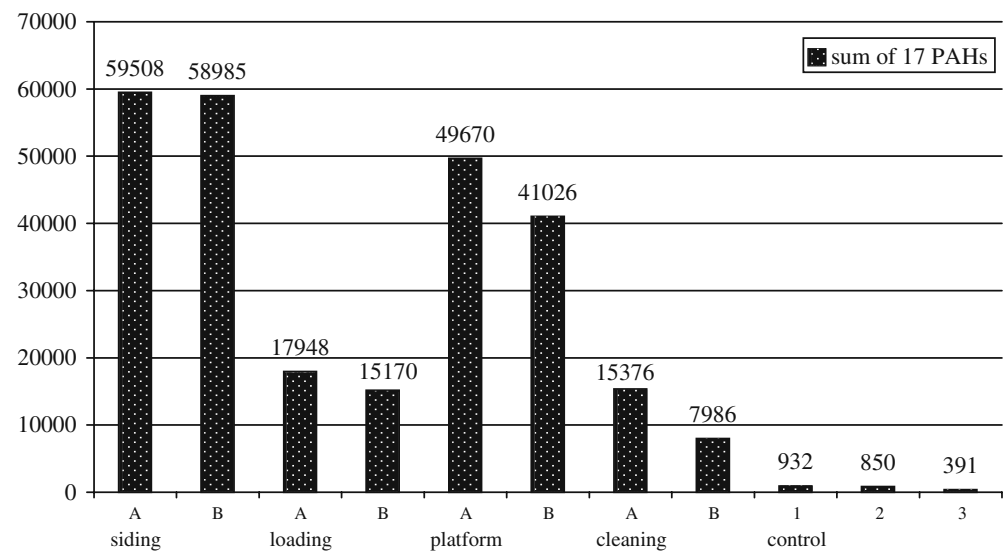


Fig. 3 The percentage content of three-, four-, five- and six-ring PAHs in railway junction Iława Główna depending on place

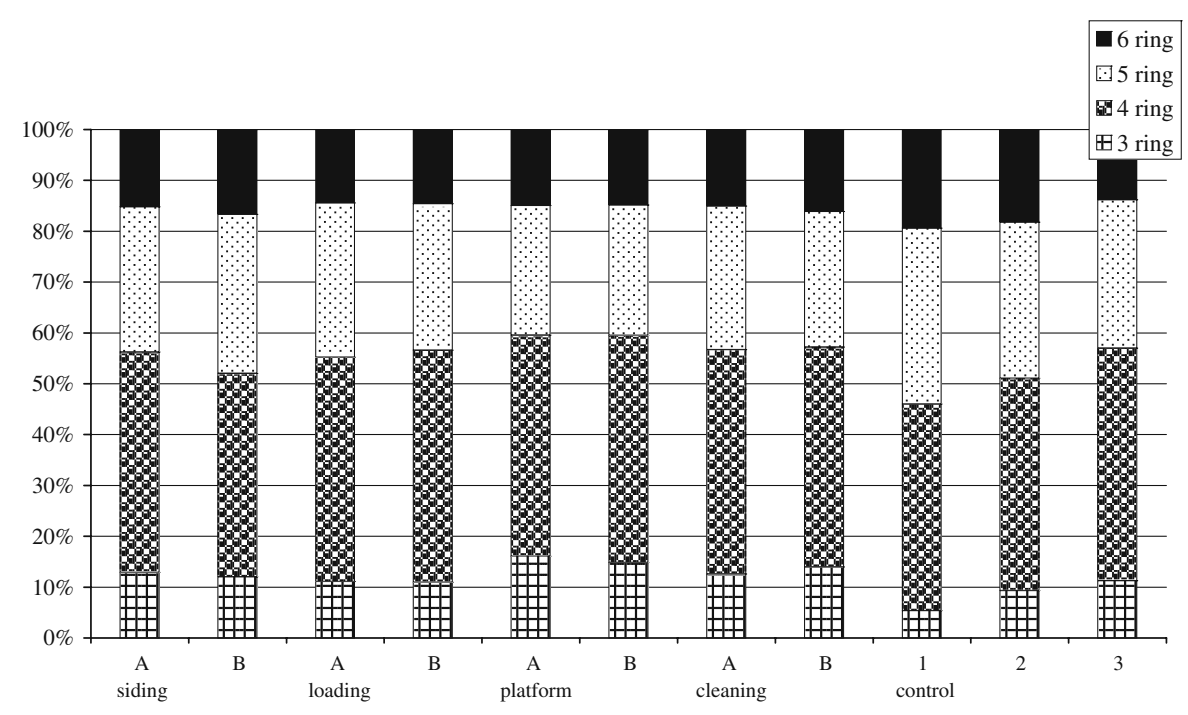

gauge was slightly higher than in the shoulder. Such a pattern of PAH levels indicates that soil contamination is mostly created either by very intensive train movement (platform) or by rolling stock remaining in one place for a long time (siding). In the loading ramp and the cleaning bay where traffic is not heavy and rolling stock remains for a relatively short time, the PAH level is less increased compared with the formerly described parts of the junction. The same distribution of contamination was observed in the past (Malawska and Wiłkomirski 2001), but currently the contamination level is much higher.

Figure 3 presented the percentage content of three-, four-, five- and six-ring PAHs in railway junction Iława Główna. It proved that the most abundant groups of hydrocarbons in soil of all the parts of the junction were four- and five-ring PAHs.

The tracks of all the investigated parts of the junction were covered by plants, although in different degree. The plant cover on track which is very heavily used within platform area was very poor. A slightly bigger plant cover was observed in the loading ramp, whereas in the railway siding and the cleaning bay, the plant cover was relatively more abundant but still rather scanty.

In all the investigated areas, 120 plant species were found (Galera et al., submitted for publication). However, the prevailing number of them was represented by one or a few specimens. Four species occurring in

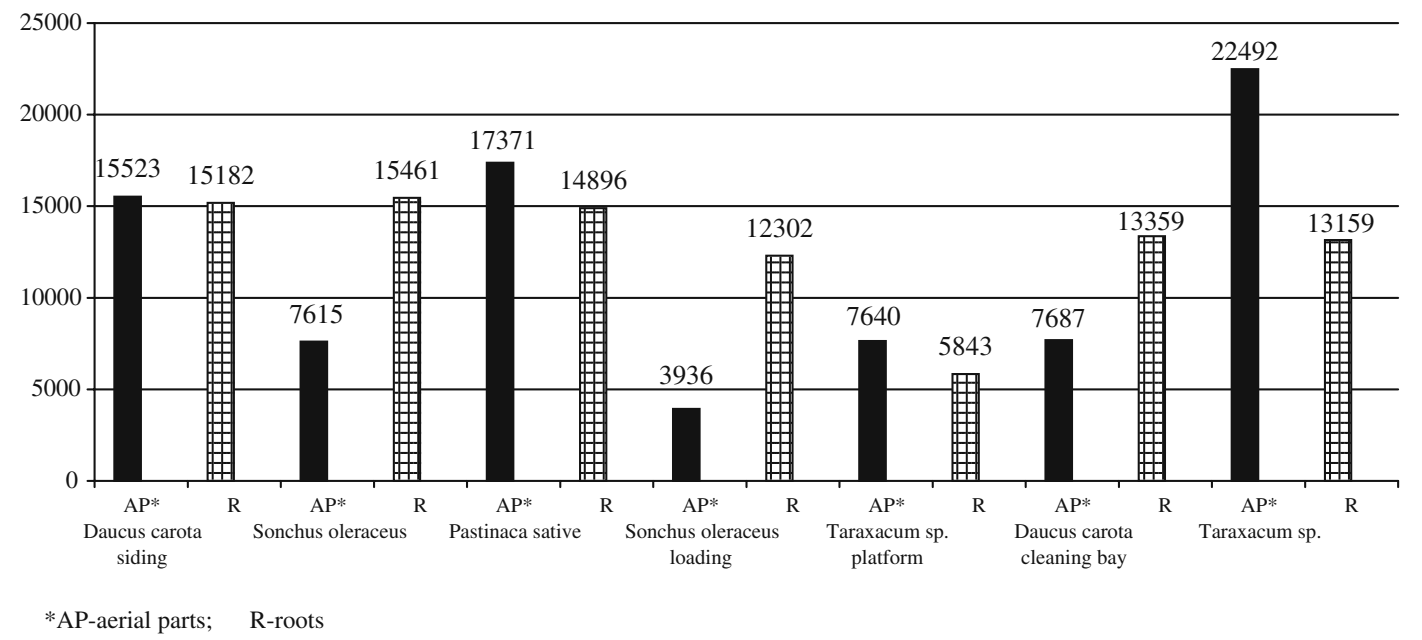

Fig. 4 The comparison of the total PAH content in different plants in railway junction Iława Główna depending on place (micrograms per kilogram) 
Table 2 Content of PAHs in plant samples (aerial parts and roots) in railway junction Iława Główna depending on place (micrograms per kilogram)

\begin{tabular}{|c|c|c|c|c|c|c|c|c|c|c|c|c|c|c|}
\hline \multirow[t]{3}{*}{ Compounds } & \multicolumn{6}{|l|}{ Siding } & \multirow{2}{*}{\multicolumn{2}{|c|}{$\begin{array}{l}\text { Loading } \\
\begin{array}{l}\text { Sonchus } \\
\text { oleraceus }\end{array}\end{array}$}} & \multirow{2}{*}{\multicolumn{2}{|c|}{$\begin{array}{l}\text { Platform } \\
\text { Taraxacum } \\
\text { sp. }\end{array}$}} & \multicolumn{4}{|c|}{ Cleaning bay } \\
\hline & \multicolumn{2}{|c|}{$\begin{array}{l}\text { Daucus } \\
\text { carota }\end{array}$} & \multicolumn{2}{|c|}{$\begin{array}{l}\text { Sonchus } \\
\text { oleraceus }\end{array}$} & \multicolumn{2}{|c|}{$\begin{array}{l}\text { Pastinaca } \\
\text { sativa }\end{array}$} & & & & & $\begin{array}{l}\text { Daucus } \\
\text { carota }\end{array}$ & & $\begin{array}{l}\text { Tarax } \\
\text { sp. }\end{array}$ & um \\
\hline & $\mathrm{AP}$ & $\mathrm{R}$ & AP & $\mathrm{R}$ & $\mathrm{AP}$ & $\mathrm{R}$ & $\mathrm{AP}$ & $\mathrm{R}$ & AP & $\mathrm{R}$ & AP & $\mathrm{R}$ & AP & $\mathrm{R}$ \\
\hline Acenaphthylene & 161 & 120 & 38 & 126 & 196 & 123 & 26 & 89 & 23 & 28 & 98 & 177 & 135 & 130 \\
\hline Acenaphthene & 840 & 66 & 63 & 63 & 1,213 & 150 & 56 & 95 & 99 & 49 & 167 & 54 & 62 & 40 \\
\hline Fluorene & 1,484 & 122 & 137 & 117 & 1,344 & 207 & 119 & 284 & 114 & 71 & 216 & 98 & 111 & 81 \\
\hline Phenanthrene & 5,600 & 1,225 & 1,363 & 1,238 & 1,000 & 1,685 & 936 & 2,170 & 1,125 & 760 & 1,938 & 769 & 1,476 & 923 \\
\hline Anthracene & 200 & 342 & 305 & 373 & 460 & 311 & 109 & 456 & 126 & 114 & 155 & 483 & 443 & 412 \\
\hline Fluoranthene & 4,200 & 1,758 & 2,600 & 1,786 & 7,800 & 2,510 & 672 & 1,404 & 1,285 & 891 & 1,929 & 1,102 & 6,600 & 2,610 \\
\hline Pyrene & 1,463 & 1,470 & 1,375 & 1,524 & 2,870 & 1,890 & 498 & 1,458 & 996 & 721 & 861 & 1,382 & 4,100 & 1,960 \\
\hline Benzo[a]anthracene & 184 & 898 & 236 & 900 & 295 & 1,014 & 194 & 777 & 482 & 380 & 230 & 500 & 763 & 582 \\
\hline Chrysene & 327 & 1,068 & 426 & 1,089 & 818 & 1,055 & 239 & 752 & 557 & 391 & 368 & 619 & 3,300 & 1,469 \\
\hline Benzo[b]fluoranthene & 294 & 2,040 & 350 & 2,130 & 504 & 1,511 & 326 & 1,364 & 857 & 576 & 482 & 2,430 & 2,260 & 1,776 \\
\hline Benzo[k]fluoranthene & 122 & 851 & 133 & 868 & 195 & 619 & 113 & 438 & 308 & 250 & 187 & 936 & 899 & 660 \\
\hline Benzo[e]pyrene & 117 & 835 & 117 & 856 & 168 & 575 & 124 & 530 & 260 & 242 & 197 & 947 & 787 & 664 \\
\hline Benzo[a]pyrene & 184 & 1,576 & 175 & 1,567 & 161 & 1,015 & 186 & 785 & 539 & 388 & 266 & 1,409 & 445 & 503 \\
\hline Perylene & 30 & 304 & 26 & 300 & 30 & 179 & 27 & 128 & 84 & 68 & 45 & 260 & 73 & 97 \\
\hline Indeno[123-cd]pyrene & 147 & 1,204 & 129 & 1,209 & 155 & 969 & 135 & 680 & 377 & 417 & 257 & 1,044 & 529 & 592 \\
\hline Dibenzo[ah]anthracene & 34 & 250 & 31 & 248 & 29 & 203 & 36 & 146 & 70 & 64 & 53 & 236 & 98 & 101 \\
\hline Benzo[ghi]perylene & 136 & 1,053 & 111 & 1,067 & 133 & 880 & 140 & 746 & 338 & 433 & 238 & 913 & 411 & 559 \\
\hline
\end{tabular}

$A P$ aerial parts, $R$ roots

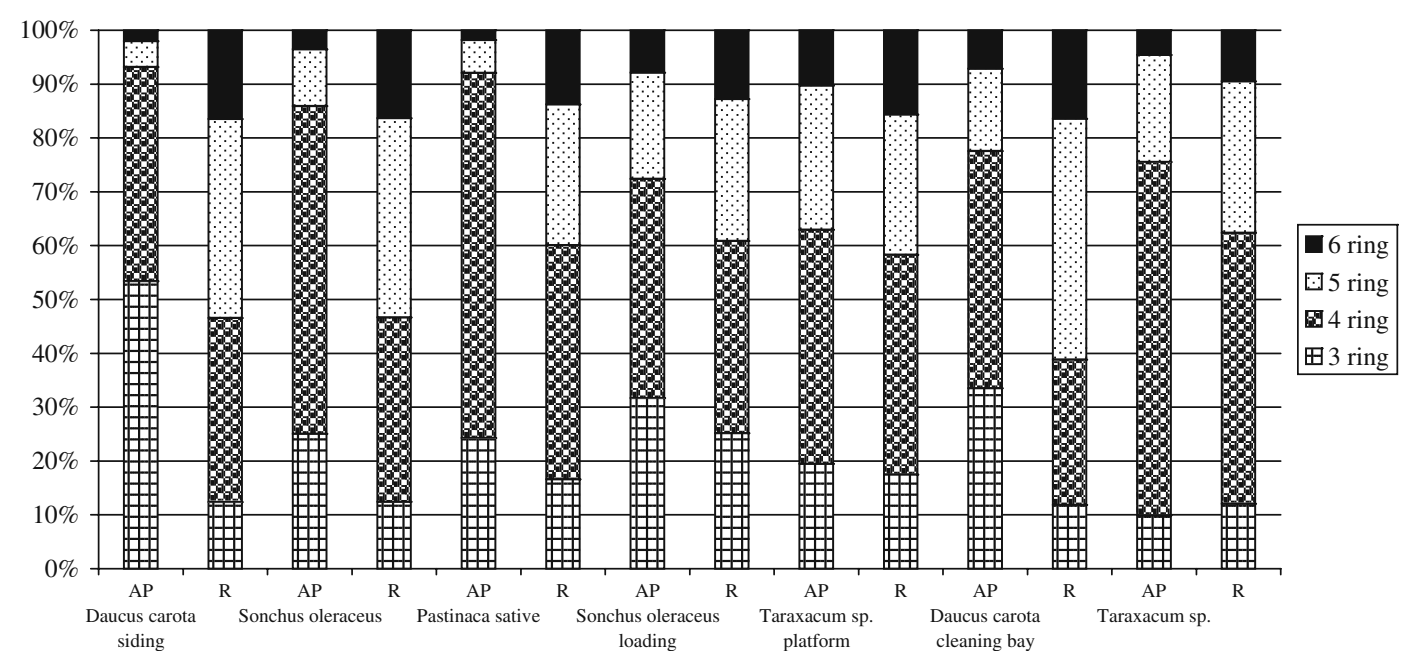

Fig. 5 The percentage content of three-, four-, five- and six-ring PAHs in aerial parts and roots of selected species growing in different parts of Iława Główna junction 
Fig. 6 The comparison of 14 PAHs content in soil in four functional parts of the railway junction Iława Główna in 1995 and 2008 years (micrograms per kilogram)

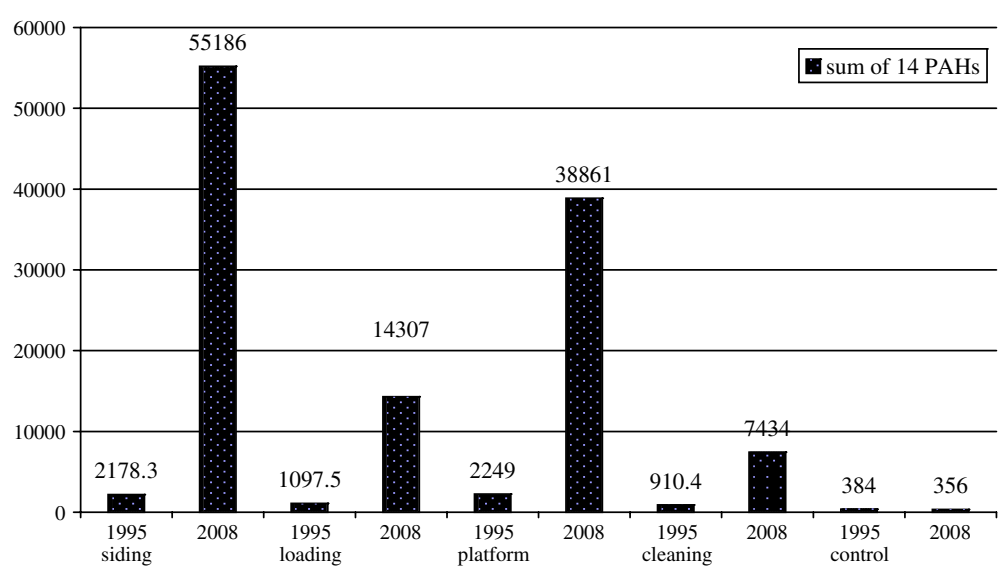

relatively higher abundance were selected for PAHs analysis, although in the loading ramp and platform areas only one species could be collected in the amount which makes chemical analysis possible. The selected species included three perennials (Daucus carota, Pastinaca sativa and Taraxacum officinale) and one annual plant (Sonchus oleraceus). All the collected plant specimens were divided into aerial parts and roots.

The comparison of PAH total content in different plants in railway junction Iława Główna is presented in Fig. 4. The highest level of PAHs $\left(22,492 \mu \mathrm{g} \mathrm{kg}^{-1}\right)$ was observed in $T$. officinale growing in the cleaning bay. The highest PAH accumulation in roots was observed in plants growing in railway siding area and reached $15,182,15,461$ and $14,896 \mu \mathrm{g} \mathrm{kg}^{-1}$ in $D$. carota, S. oleraceus and $P$. sativa, respectively.
Table 2 shows the PAH content in the aerial parts and roots of a selected plant in the investigated areas of the junction.

The percentage content of PAHs possessing different numbers of rings in the molecule in aerial parts and roots of selected species growing in different parts of Iława Główna junction was presented in Fig. 5. The most abundant group of PAHs present in plants in the investigated areas is represented by four-ring PAHs. Plants of three species growing in the railway siding differ from other investigated plants by a much smaller amount of five- and six-ring PAHs in aerial parts.

The present study was carried out in September 2008. Thirteen years ago in the same study area, the following 14 PAHs were determined: acenaphthene, fluorene, phenanthrene, anthracene, fluoranthene, pyrene,
Fig. 7 The comparison of the 14 PAHs content in aerial parts of different plants from the area of Iława Główna railway junction in 1995 and 2008 (micrograms per kilogram)

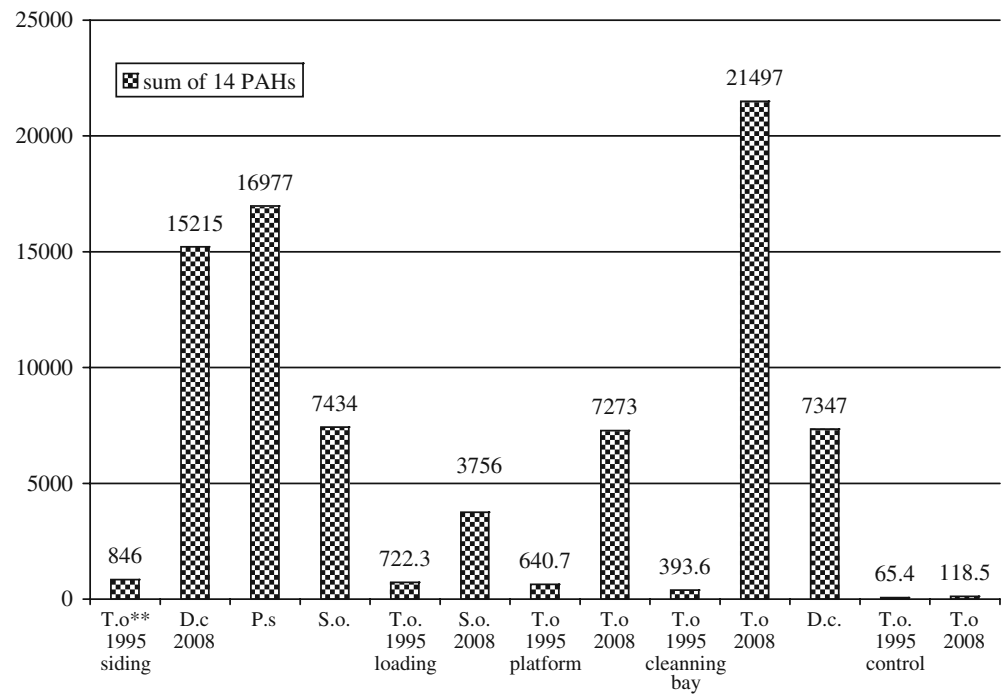


Fig. 8 a The percentage content of three-, four-, five- and six-ring PAHs in soil collected in 1995 and 2008 depending on place. b The percentage content of three-, four-, five- and six-ring PAHs in plants collected in 1995 and 2008 depending on place
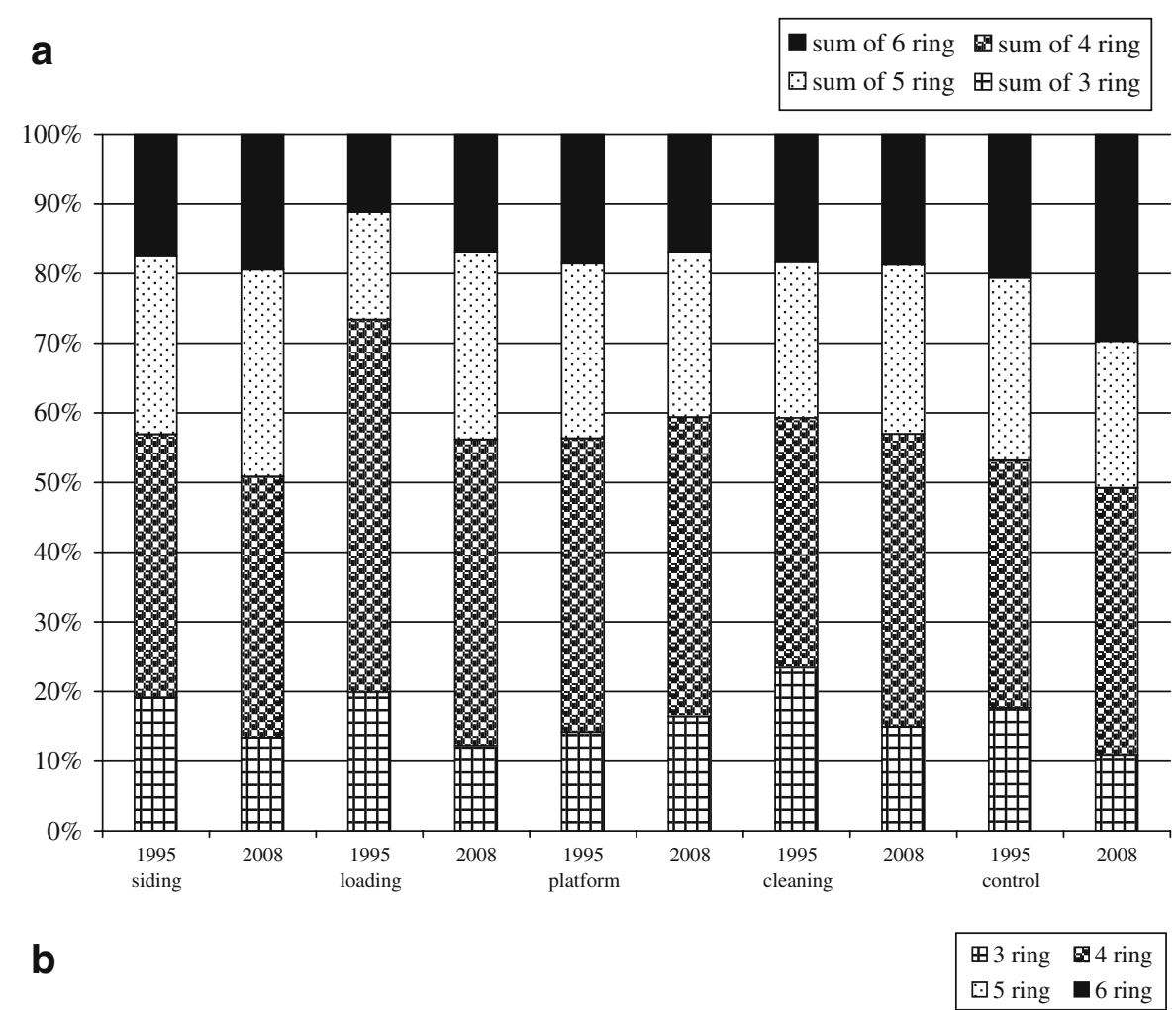

benzo(a)anthracene, chrysene, benzo(b)fluoranthene, benzo(k)fluoranthene, benzo(a)pyrene, indeno(123-cd) pyrene, dibenzoanthracene and bezo(ghi)perylene (Malawska and Wiłkomirski 2001). The comparison of earlier findings with the results indicating the total level of the same 14 PAHs determined in the present study showed a very significant increase of PAHs content in all the functional parts of the railway junction Ilawa Główna. At the same time, the PAH level in the control areas did not change. The comparison of the total level of 14 investigated PAHs in the soil of the different parts of the junction (in 1995 and 2008) is presented in Fig. 6.

According to the data obtained from Polish Rail Regional Head Office in Olsztyn, the different parts of the railway junction Iława Główna were renovated (including the replacement of ballast bed and railway ties): cleaning bay in 1978, track no. 7 in 1977 , loading ramp in 1984 and railway siding in 1991. Between our former investigations and the present study, no other renovation was carried out. Hence, the 
Table 3 Content of heavy metals in soil samples collected in the railway junction Iława Główna depending on place (milligrams per kilogram)

\begin{tabular}{|c|c|c|c|c|c|c|c|c|c|c|c|}
\hline \multirow[t]{2}{*}{ Heavy metals } & \multicolumn{2}{|l|}{ Siding } & \multicolumn{2}{|l|}{ Loading } & \multicolumn{2}{|l|}{ Platform } & \multicolumn{2}{|c|}{ Cleaning } & \multicolumn{3}{|c|}{ Control } \\
\hline & $\begin{array}{l}\text { Soil } \\
A\end{array}$ & $\begin{array}{l}\text { Soil } \\
B\end{array}$ & $\begin{array}{l}\text { Soil } \\
A\end{array}$ & $\begin{array}{l}\text { Soil } \\
B\end{array}$ & $\begin{array}{l}\text { Soil } \\
A\end{array}$ & $\begin{array}{l}\text { Soil } \\
B\end{array}$ & $\begin{array}{l}\text { Soil } \\
A\end{array}$ & $\begin{array}{l}\text { Soil } \\
B\end{array}$ & $\begin{array}{l}\text { Soil } \\
1\end{array}$ & $\begin{array}{l}\text { Soil } \\
2\end{array}$ & $\begin{array}{l}\text { Soil } \\
3\end{array}$ \\
\hline Lead & 448 & 494 & 75 & 84 & 193 & 177 & 134 & 204 & 8 & 11 & 6 \\
\hline Cadmium & 5.4 & 5.1 & 7.4 & 0.8 & 2.5 & 1.3 & 1.3 & 1.9 & n.d. & n.d. & n.d. \\
\hline Copper & 191 & 161 & 33 & 37 & 480 & 326 & 105 & 418 & 4 & 4 & 4 \\
\hline Zinc & 1,264 & 1,223 & 206 & 228 & 1,438 & 897 & 357 & 563 & 23 & 23 & 18 \\
\hline Mercury & 0.573 & 0.969 & 0.066 & 0.046 & 0.165 & 0.144 & 0.678 & 0.757 & 0.014 & 0.050 & 0.013 \\
\hline Iron & 44,800 & 39,700 & 14,600 & 11,900 & 112,900 & 59,700 & 24,900 & 34,300 & 4,400 & 4,500 & 5,000 \\
\hline Cobalt & 9 & 8 & 3 & 3 & 14 & 6 & 5 & 6 & 1 & 1 & 2 \\
\hline Chromium & 67 & 58 & 14 & 11 & 208 & 62 & 23 & 33 & 5 & 6 & 8 \\
\hline Molybdenum & 2 & 2 & n.d. & n.d. & 8 & 4 & 1 & 1 & n.d. & n.d. & 1 \\
\hline
\end{tabular}

13 years of intensive railway use led to the substantial increase of the PAHs level in soil.

Similar analysis also indicated a remarkably high contamination of plants with PAHs compared with previous investigations. The control made for $T$. officinale did not show the increase of the contamination. These results are presented in Fig. 7. Very interesting results are presented in Fig. 8 showing the proportion between PAHs possessing different number of rings in the molecule.

The significant percentage of five- and six-ring PAHs in the soil (ranging from about 25\% to about $50 \%$ ) is very characteristic. This percentage is different in the case of plants. The lack of five- and six-ring PAHs in plants growing in control areas and the small percentage of these compounds in plants growing within railway junction suggested that railway transport is a source of serious pollution with PAHs. It seems that the content of "heavy" PAHs in the soil is associated with the permanent and long cumulative deposit, whereas plants reflect rather current deposit connected with railway emission. This is in accordance with the observations concerning the different uptake pathways of contaminants into plants (Trapp 1995; Barber et al. 2004). The smaller percentage of the "light" PAHs could also be connected with their evaporation from the soil. Such tendencies were observed both in 1995 and 2008.

The levels of the investigated heavy metals were determined in soil samples and selected plants. The heavy metal contents in soil are presented in Table 3.
The levels of nine heavy metals $(\mathrm{Pb}, \mathrm{Cd}, \mathrm{Cu}, \mathrm{Zn}$, $\mathrm{Hg}, \mathrm{Fe}, \mathrm{Co}, \mathrm{Cr}, \mathrm{Mo}$ ) were established. The highest level of lead, which exceeded the control level approximately 50 -fold, was determined in the siding area. In other parts of the junction, the lead level was lower and exceeded the control value by ca. tenfold, 22-fold and 20-fold, respectively. The cadmium level is rather low in all the investigated areas. However, in the area of siding and in railway gauge of the loading ramp, the level of cadmium is higher than in other parts of the junction. The highest concentration of copper was detected in the platform area, what is easy to understand due to the intensive action of pantographs on trolley wires (track 7 is intensively used by passenger trains and some of them do not stop at the station, passing through with a high velocity).

The whole area of the junction contains elevated concentration of zinc. The highest concentration of this metal was observed on the siding, exceeding the control level approximately 60-fold. A significant increase in mercury content was observed in the cleaning bay area and in the railway siding. In both areas, the average mercury concentration exceeded the control level about 30 times.

Cobalt and molybdenum concentrations in the soil of all the investigated areas were relatively low. Iron contamination of soil is high in all the functional parts of the junction, especially in the platform area where in the railway gauge its level reached ca. $11 \%$, justifying the common name of the railway. Chromium contamination varied reaching the highest level in the rail 
煦

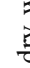

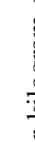

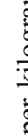

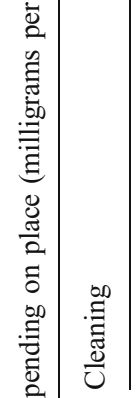

高

䒿

宅

言

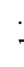

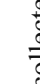

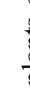

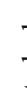

宽

昰
茛

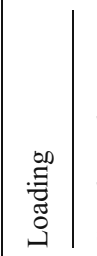

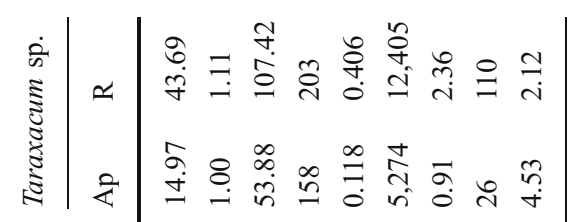

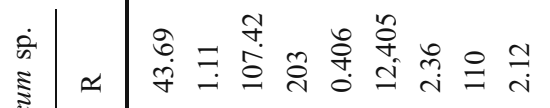

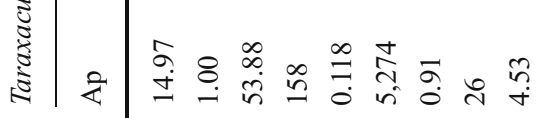

₹

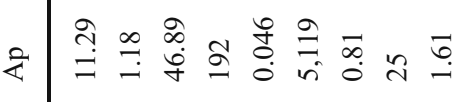

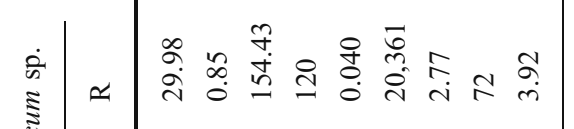

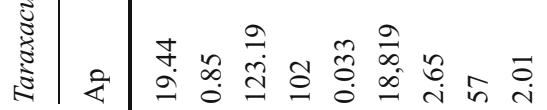

$y \mid$

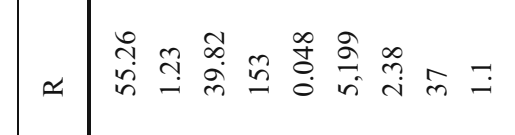

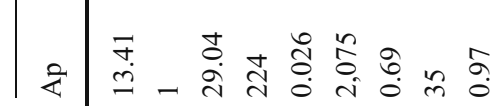

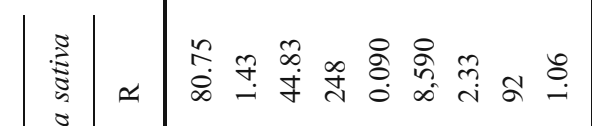

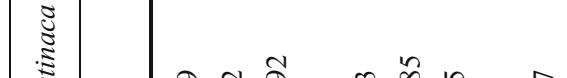

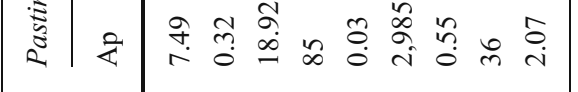

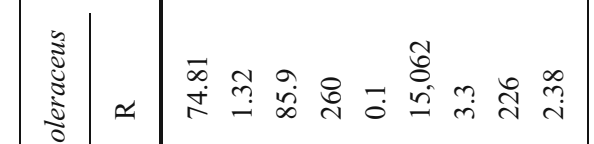

范

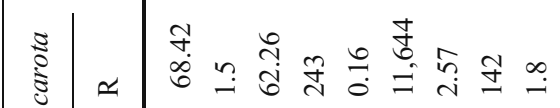

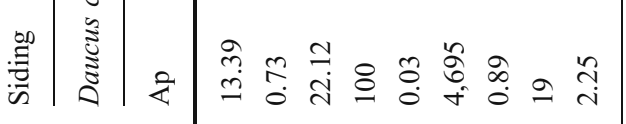

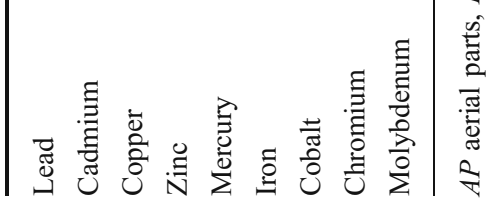

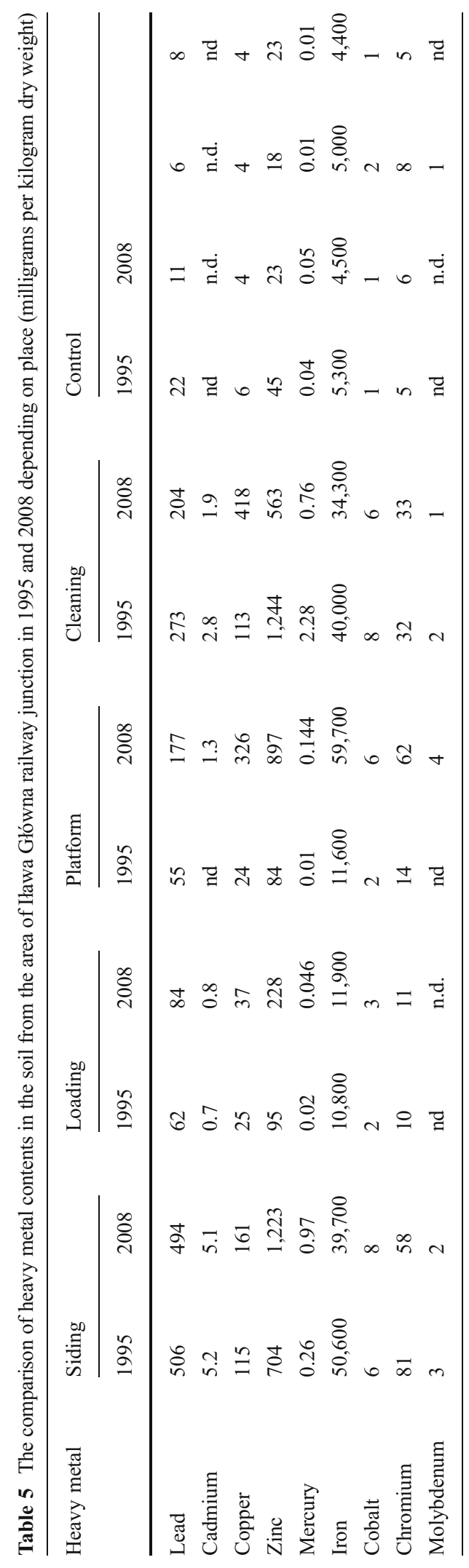


gauge in the platform area. Generally, the contamination of soil with all the heavy metals, except mercury, was higher in the railway siding and platform area and lower in the loading ramp and cleaning bay.

With regard to the railway studies, Liu et al. (2009) reported the levels of heavy metals alongside mountain railway in China. These concentrations were comparable to our results. The heavy metal contents in roots and aerial parts of selected plants collected in different functional parts of the junction are presented in Table 4.

In nearly all the investigated plants, the contents of heavy metals were higher in roots than in aerial parts. A different tendency was demonstrated only in the case of molybdenum.

The concentration of PAHs in the area of railway junction significantly increased from 1995 to 2008. The heavy metal concentration did not change considerably during this period. We assumed that this was connected with the railway ballast permeability making the leaching of soluble contamination possible. The comparisons of heavy metal contents in 1995 and 2008 in soil and plants are presented in Tables 5 and 6, respectively.

The statistical analysis showing the dependence between contents of contaminants in plants and soil is presented in Table 7. The obtained results show:

1. High positive dependence between $\mathrm{Cu}, \mathrm{Fe}$ and $\mathrm{Hg}$ (lower) contents in soil and the amount of these metals in aerial parts of plants

2. High positive dependence between $\mathrm{Pb}, \mathrm{Cu}, \mathrm{Fe}$ and $\mathrm{Hg}$ (lower) contents in soil and the amount of these metals in roots of plants

3. High positive dependence between $\mathrm{Cu}, \mathrm{Hg}$ and $\mathrm{Fe}$ contents in aerial parts and roots

The described values indicate that these elements are absorbed by the root system from the soil and transported to leaves. The high dependence between $\mathrm{Pb}$ content in soil and roots and lack of such dependence between $\mathrm{Pb}$ content in soil and aerial parts indicate that lead is absorbed from the soil and deposited in roots. The dependences between $\mathrm{Cd}$ content in soil and roots as well as in soil and aerial parts are not observed, although the relationship between the content of this element in roots and aerial parts is highly positive which suggest mobility of cadmium. The content of each heavy metal in the 
Table 7 The correlation coefficient between heavy metals and PAH contents in aerial parts and roots of plants and soil $(P<0.005)$

\begin{tabular}{lrrrrrrr}
\hline & $\mathrm{Pb}$ & $\mathrm{Cd}$ & $\mathrm{Cu}$ & $\mathrm{Zn}$ & $\mathrm{Hg}$ & $\mathrm{Fe}$ & The sum of PAHs \\
\hline Soil vs AP & -0.5 & -0.5 & 0.8 & -0.9 & 0.5 & 0.9 & 0.3 \\
Soil vs R & 0.8 & -0.2 & 0.8 & 0.4 & 0.6 & 0.9 & -0.1 \\
AP vs R & -0.7 & 0.8 & 0.9 & -0.5 & 0.9 & 0.8 & 0.3 \\
\hline
\end{tabular}

soil of all the investigated parts of the railway junction exceeded the average amount of these elements in Poland's soils (Kabata-Pendias and Pendias 1999).

No relationship between the total content of PAHs in soil and plants was found, which indicates that these compounds are deposited from the atmosphere and are not absorbed by the root system. In Poland, the assessment of soil quality is carried out based on different classifications, i.e. National Research Institute (Institute of Soil Science and Plant Cultivation, ISSPC) system (sum of 13 PAHs), Ministry Regulation (sum of nine PAHs) and Dutch List (sum of ten PAHs). Table 8 shows the comparison of PAHs content and soil assessment.

The Institute of Soil Science and Plant Cultivation in Pulawy proposed the classification of agricultural soil contaminated with PAHs, which is often used in Poland. According to this classification, PAH content in agricultural soil below $200 \mu \mathrm{g} \mathrm{kg}^{-1}$ can be considered as "background level", whereas the range from 200 to $600 \mu \mathrm{g} \mathrm{kg}^{-1}$ is characteristic of unpolluted soil with slightly increased PAH content. The sum of PAHs $\left(600-10,000 \mu \mathrm{g} \mathrm{kg}^{-1}\right)$ corresponds to the contaminated soil with different levels of contamination, and the content of these compounds exceeding $10,000 \mu \mathrm{g} \mathrm{kg} \mathrm{kg}^{-1}$ corresponds to very heavily contaminated soils where reclamation is needed.

The soil from all the investigated parts of the railway junction Iława Główna is heavily polluted type (class $5^{\circ}$ ). The only exception is surface $B$ (outside the rails) in the cleaning bay, where the level of PAH contamination places the soil in class $4^{\circ}$.

According to the Ministry Regulation, all the parts of the investigated railway junction are covered by the polluted soil. According to the Dutch List, the soil from the area of the railway siding and platform are too heavily polluted (class $3^{\circ}$ ) and the soil from the area of loading ramp and cleaning bay is polluted (class $2^{\circ}$ )

\section{Conclusions}

In order to summarise the above results, it should be stated that railway transport may be an important threat to the natural environment. This concerns especially PAH contamination. Since the PAH level is much higher in the area of all the functional parts of the junction than in the surrounding areas, it seems necessary to monitor the level of contamination in all the intensively used railway infrastructure. The determination of extremely high level of contamination should be a signal for renovation including the change of ballast bed and railway wooden ties for concrete ones. This is especially important in the railway siding where trains remain in one place for a long time and in platform area where the train movement is very intensive. The heavy metal concentration in the area of railway junction is also high, although not so extreme as in the case of PAHs. The

Table 8 Standard limiting PAH content in the soil surface layer (micrograms per kilogram)

\begin{tabular}{|c|c|c|c|c|c|c|}
\hline Class & 1 & 2 & 3 & 3 & 4 & 5 \\
\hline $\begin{array}{l}\text { ISSPC } \\
\qquad(13 \text { PAHs })\end{array}$ & $\begin{array}{l}\text { 0-200 unpolluted } \\
\text { (natural content) }\end{array}$ & $\begin{array}{l}200-600 \text { unpolluted } \\
\text { (increased content) }\end{array}$ & $\begin{array}{l}600-1,000 \text { slightly } \\
\text { polluted }\end{array}$ & $\begin{array}{l}1,000-5,000 \\
\text { polluted }\end{array}$ & $\begin{array}{l}5,000-10,000 \\
\text { heavily polluted }\end{array}$ & $\begin{array}{l}\text { up to }>10,000 \\
\text { very heavily } \\
\text { polluted }\end{array}$ \\
\hline $\begin{array}{l}\text { Ministry of } \\
\text { Environment } \\
\text { (9 PAHs) }\end{array}$ & $<1,000$ unpolluted & $>1,000$ polluted & $>40,000$ & & & \\
\hline $\begin{array}{l}\text { Dutch List } \\
\text { (10 PAHs) }\end{array}$ & $<1,000$ unpolluted & $\begin{array}{l}1,000-40,000 \\
\text { polluted }\end{array}$ & Heavily polluted & & & \\
\hline
\end{tabular}


railway siding and the platform area are the places highly contaminated with heavy metals.

Acknowledgements We wish to acknowledge our indebtedness to the Ministry of Science and Higher Education for grant no. N305 076 32/2694 which made this work possible. We are also very grateful to Polish Rail Regional Head Office in Olsztyn for permission to investigate the railway junction Iława Główna and for essential information about exploitation of particular functional parts of the junction.

Open Access This article is distributed under the terms of the Creative Commons Attribution Noncommercial License which permits any noncommercial use, distribution, and reproduction in any medium, provided the original author(s) and source are credited.

\section{References}

Barber, J. L., Thomas, G. O., Kerstiens, G., \& Jones, K. C. (2004). Current issues and uncertainties in the measurement and modeling of air-vegetation exchange and within-plant processing of POPs. Environmental Pollution, 128, 99-138.

Brooks, K. M. (2004). Polycyclic aromatic hydrocarbon migration from creosote-treated railway ties into ballast and adjacent wetlands. Research Paper FLP-RP-617. Madison: Department of Agriculture, Forest Service, Forest Products Laboratory.

Bukowiecki, N., Gehrig, R., Hill, M., Lienemann, B., Zwicky, C. N., Buchmann, B., et al. (2007). Iron, manganese and copper emitted by cargo and passenger trains in Zurich (Switzerland): Size-segregated mass concentrations in ambient air. Atmospheric Environment, 41, 878-889.

Chillrud, S. N., Grass, D., Ross, J. M., Coulibaly, D., Slavkovich, V., Epstein, D., et al. (2005). Steel dust in the New York City subway system as a source of manganese, chromium and iron exposures for transit workers. Journal of Urban Health, 82, 33-42.

IARC. (1983). Polynuclear aromatic compounds. Part I, chemical, environmental and experimental data, monographs on the evaluation of the carcinogenic risk of chemicals to humans. Vol. 32. Lyon: International Agency for Research on Cancer.

Kabata-Pendias, A., \& Pendias, H. (1999). Biogeochemistry of trace elements (in Polish). Warszawa: Wydawnictwo Naukowwe PWN.

Lacey, R. F., \& Cole, J. A. (2003). Estimating water pollution risks arising from road and railway accidents. Quarterly Journal of Engineering Geology and Hydrogeology, 36(2), 185-192.

Liu, H., Chen, L. P., Ai, Y. W., Yang, X., Yu, Y. H., \& Zuo, Y. B. (2009). Heavy metal contamination in soil alongside mountain railway in Sichuan, China. Environmental Monitoring and Assessment, 152, 25-33.

Moret, S., Purcaro, G., \& Conte, L. S. (2007). Polycyclic aromatic hydrocarbon (PAH) content of soil and olives collected in areas contaminated with creosote released from old railway ties. The Science of the Total Environment, $386,1-8$.

Malawska, M., \& Wiłkomirski, B. (1999). An analysis of polychlorinated biphenyls (PCBs) content in soil and plant leaves (Taraxacum officinale) in the area of the railway junction. Iława Główna, 70, 509-515.

Malawska, M., \& Wiłkomirski, B. (2000). Soil and plant contamination with heavy metals in the area of the old railway junction Tarnowskie Góry and near two main railway routes. Roczniki Państwowego Zakładu Higieny, 51(3), 259-268.

Malawska, M., \& Wiłkomirski, B. (2001). An analysis of soil and plant (Taraxacum officinale) contamination with heavy metals and polycyclic aromatic hydrocarbons (PAHs) in the area of the railway junction Ilawa Główna, Poland. Water, Air, and Soil Pollution, 127, 339-349.

Thierfelder, T., \& Sandström, E. (2008). The creosote content of used railway crossties as compared with European stipulations for hazardous waste. The Science of the Total Environment, 402, 106-112.

Trapp, S. (1995). Model for uptake of xenobiotics into plants. In S. Trapp \& J. C. McFarlane (Eds.), Plant contamination modelling and simulation of organic chemical processes (pp. 107-151). London: Lewis. 